\title{
THE CONCEPT OF EUROPEANIZATION AND BALKAN COUNTRIES: SERBIA, BULGARIA AND ROMANIA EXAMPLES
}

\section{AVRUPALILAŞMA KAVRAMI VE BALKAN ÜLKELERİ: SIRBİSTAN, BULGARISTAN VE ROMANYA ÖRNEKLERI}

Caner Övsan ÇAKAŞ ${ }^{1}$

\begin{abstract}
Europeanization is a profound issue that impact the both domestic and foreing policies of the member states, quasi-member states, candidate states, neighbour states and other states of the world. The reason of the European impacts in these large geographies may be market power of the European Union and political, social and cultural powers of the Union. In this research, definition of the Europeanization, its mechanism and its transformative effects will be elaborated in three Balkan countries, namely Serbia, Bulgaria and Romania. The main arguments of the research is that the Europeanization could not provide the effective transformations in the foreign policies of Serbia and domestic policies of the Bulgaria and Romania. At the end of the research study it has reached that this failure of Europanization in these countries is correlated with the preferences of the ruling elites in these countries.
\end{abstract}

Key Words: Europeanization, Foreign Policy, Domestic Policy, Serbia, Bulgaria, Romania

Jel Codes: Z19

Öz

Avrupalılaşma, AB üyesi ülkelerin, aday ülkelerin, AB’nin komşu ülkelerinin ve AB ile ilişkisi bulunan dünyanın diğer ülkelerinin iç ve dış politikalarını etkileyen derin ve büyük bir konudur. Avrupalılaşmanın bu etkisinin nedeni ise AB'nin siyasi, sosyal, kültürel ve ekonomik gücünden kaynaklandığg kabul edilebilir. Bu çalışmada ise Avrupalılaşmanın tanımı, mekanizması ve Sırbistan, Bulgaristan ve Romanya olmak üzere üç Balkan ülkesinde vuku bulan dönüştürücü etkileri ele alınmıştır. Çalışma sürecinde Avrupalılaşmanın Sırbistan'ın dış politikalarında ve Bulgaristan ve Romanya'nın ise iç politikalarında etkili dönüşümler sağlayamadığı tespit edilmiştir. Araştırma çalışmasının sonunda, bu başarısızlığın sebebinin bu ülkelerdeki yönetici elitlerin tercihleri ile bağlantılı olduğu sonucuna varmıştır.

Anahtar Kelimeler: Avrupalılaşma, Dış Politika, İç Politika, Sırbistan, Bulgaristan, Romanya

Jel Kodlar: Z19

\section{Introduction}

Europeanization is profound and large issue that impact the both domestic and foreign policies of the member states, quasi-member states, candidate states, neighbour states and other states of the world. The reason of the European impacts in these large geographies may be market power of the

\footnotetext{
${ }^{1}$ Dr., Dokuz Eylül Üniversitesi AB Birliği A.B.D. , ovsancakas@ hotmail.com, ORCID: 0000-0003-0199-7765
} 
European Union and political, social and cultural powers of the Union. In this research, definition of the Europeanization, its mechanism and its transformative effects will be elaborated in three Balkan countries, namely Serbia, Bulgaria and Romania. The Europeanization or transformative effects of the European Union has accomplished the transformations the foreign and domestic policies of the member states and candidate states (specially in Eastern European states) at the end of the Second World War and Cold War. The European rules, norms, practice, political discourses has prevailed to Europe and beyond. The Europeanization of the foreign policies in the core member states of the Union, provided the end of the historical enmities in the Europe such as Germany and France relations, it also entailed establishment of the peaceful relationships among the European states in the realm of their problematic political issues. The Europeanization also culminated in transformations in the domestic policies of the member states such as respect for human rights, international law, rule of law and it provided the establishment of the democratic and inclusive political institutions in domestic structures of the many European states. On the other hand, the Europeanization could not culminated in effective transformation in neighbour and Balkan countries as it in the core member states of the EU. The process of Europeanization has confronted serious problems in these countries due to historical political, demographic, economical and sociological problems. In this research, first section elaborates the definition and mechanism of the Europeanization in member states, quasi-member states, candidate states and neighbour states. In the second section, I will consider the impacts of the Europeanization in the foreign policies of Serbia and in domestic policies of the new member states of Bulgaria and Romania. In these three case studies the contradictions of the Europeanization process will be elaborated. The conclusion section will be take into consideration the inefficieny of the Europeanization process in these countries and their reasons.

\section{Europeanization: Definition and Mechanism}

\subsection{Definition of Europeanization}

The Europeanization stresses the adoption of the entire acquis communautaire (body of the European Law) which provides rules and mechanisms to regulate the behavior of the public and private actors across the great variety of integrated policy areas (Schimmelfenning, 2010: 3). According to Radaelli, Europeanization is adaption of "European Governance" in domectic and foreign policies of the member states which incoporates formal and informal rules, procedures, policy paradigms, styles, 'way of doing things' and public policy (Radelli \& Featherstone, 2003: 30). In the other words, Europeanization means adaption of the principles of European Governance which are structured in the Union level, in the realm of the logic of domestic discourse, identities, political structures and public policies (Lavenex \& Schimmelfenning, 2009: 795). It is also important to make exactly definition of the European Governance which constitudes the basic foundation of the Europeanization. The European Governanace includes regionalism, supranational integration, 
multilateralism, transnational markets, the regulatory state and constitutionalism (Farrell, 2007: 299315). Regionalism stresses the importance of the regional intergration processes in the entire world. According to this assumption, the regional integrations which are realized in the fields of economic, political, sociological or commercial issues, promotes the regional stability and peaceful relations, and general welfare in the regions of the world (Wallace, 1999: 201-223). Consequently, it should be assumed that the Europe attempts to provide realization of its own experiences in all the problematic regions of the globe. The Europe had the experiences of the two World War in the past which were culminated in total destruction of the region and Europe had suffered from the historical enmities of the national states many times in the past, but Europe overcame from these problems by means of regional intergration and provided a stable, wealthy and peaceful union like the assumption of the Immanuel Kant's "perpetual peace" theory (Kant, 2014: 10). Thus any parts of the world can accomplish the same structure by means of regional integration. The regionalism also must be supplemented by the other aspects of the European Governance. The multilateralism emphasises the multilaterally regulations of the political and economic issues. Rather than the unilateral administrations of the issue, the multilaterallism presupposes the inclusive decision making process which takes into consideration the active or pasive support of all the parties in the realm of the political issue and it provides more legitimacy to related issues (Owen, 1994: 87-89). As a political preference, European Governance, also struggles to promote intensive multilateralism not only in the Europe, but also in the globe (Schimmelfenning, 2010: 6). The European Governance also promotes the creation and regulation of the transnational markets which provides the economical interdependence among the regional and global states and it enables not only desecuritization of the foreign policies of the parties which will be very costly to deal with the political problems by means of hard power due to high economical interdependence, but also supplies the economical development of the states and provides the wealthy for public by means of reduced commericial costs and competitive markets (Keohane, 1993: 13-17). According to Willians, desecuritization is the process of moving issues off the security agenda and back into the realm of public political discourse and normal political dispute and accomodation (Williams, 2003: 515). In the other words, European Governance promotes the neoliberal economic model which stipulates the free markets and economic liberalizations among the states (Wallance, 2003: 223). The European Governance implies the regulatory state which stresses the capacity and power of the respective state to implement and regulate its rules and authority in the realm of the administrative issues, in the other words, the EU regards itself as a regulatory model of policy making and for the purpose of implementinting its regulated rules and norms, there must be effective state administration structure in respective state which Europeanization will be implemented (Grugel, 2004: 616). Finally, the European Governance gives great importance to democratic constitutionalism (Schimmelfenning, 2010: 7). Democratic constitutionalism, emphasizes the constitunal norms such as human rights, rule of law, democratic election systems, minority rights, 
gender and racial equality, personel freedoms such as freedom of speech, religion and move, free media, and transparent governmental structures (Eroğlu, 2008: 133-145). The democratic constitutionalism is also the most important complementory part of the "European Identity" together with the transnational market regulations, it provides the basic values of to be an European Nation and all the treaties which constitutes the foundation of the European Union stressed the importance of the democratic structure of state administration (Subotic, 2010: 577). EU promotes these norms beyond its borders and its external relations. Since 1990's EU has made promotion of human rights and democracy as its most important feature of its external relations in the globe (Majone, 2008: 3-11).

It should be assumed that the concept of European Governance, as indicated above, is the realization of Immanuel Kant's perpetual peace theory which depends on the establishment of transnational market and democratic governmental institutions in a respective region. According to this theory free trade and democratic institutions will create an inclusive economic and political systems in a respective region (Acemoğlu, 2013: 76-89). As a consequence of this inclusive economic and political system, regional prosperity and stability of a region will be increased and the states in this respective region will transform their intersubjective understandings and identities towards the peaceful engagements of the regional problems (Behnke, 2006: 62-69). The Europeanization is the domestic impact of, and adaptation to, European Governance which was explained above, in the EU's member states, candidate states and neighbour states. In the other words, Europeanization is the transformation of the domestic and foreign policies and political identities of the respective states in line with European level regulated norms, rules, identities and political discourses (Lavenex, \& Schimmelfennig, 2009: 795).

The impact of the Europeanization also has dependent and independent variables. In this research, presence of the European Idea, Location of Power in the respective state and Agents of Europeanization in the respective state will be regarded as the independent variables of the Europeanization proces, on the other hand, transformations in the domestic and foreign policies of the respective state, or in the other words, the Europeanization degree of the respective state will be regarded as dependent variable. The presence of "European Idea" means broadly shared social commitment to Europe as the foundational state identity (Johnson, 2001: 487). According to this assumption, if the EU is considered a desirable aspiration group whose collective identity, values, and norms respective states and societies already share and to which they want to belong, the process of Europeanization will be easier amd more complete (Johnson, 2001: 489-491). On the other hand, if the "European Idea" is not a constitutive part of the respective state's political identity but is replaced by other foundational values and norms of territory, nation, ethnicity, religion, then Europeanization will be more difficult to achieve. Thus, the extent to which becoming "European" is a social value that trumps other competing domestic political values as well as interests will guide the course of Europeanization in a respective state (Johnson, 2001: 499-501). In this context, it should be considered 
that the presence of the "European Idea" is correlated with the geographic location of the respected state too. If one accepts the 15 members of the EU before the east enlargement as the core states, the 2004 enlargement could be assessed first periphery, and 2007 enlargement could be assessed as second periphery and the candidate states third periphery, the neighbour states fifth periphery and lastly the other states could be regared as sixth periphery, thus the effect of "European Idea" and attachments to its main values weakens by way from core to sixth periphery. The second independent variable is location of the power in the respective state. The regime type of the respective state is very important factor for determining the location of power in a respective state. In the other words, the regime type, namely authoritarian, democratic, or mixed political groupings are determinants of success or failure of Europeanization (Schimmelfenning, 2010: 7-8). However, for transitional states, such as EU candidate states, the democratization level of the state, the political power of the former authoritarians, the impacts of the former regimes' policy-makers in the domestic political area, their repression apparatus' power in the state institutions such as in the armed forces, proportion of their cost due to Europeanization and their economical, sociological and politcal effectiveness in the dometic issue are directly effects the course of the Europeanization (Schimmelfenning, 2010: 11-12). If Europeanization is set to fundamentally alter their place in the new state order and their removal from position of power and control, the transitional elites will fear political reprisal, even a coup, and will be reluctant to destabilize the country and jeopardize their own power by complying with international rules (Vachudova, 2005: 100-107). The thirth independent variable is agents of the Europeanization in the respective state. This variable is mainly correlated with the strategies of the domestic political eilts who acts as agents of the Europeanization in the respective state (Subotic, 2010: 588-590). Subotic grouped these elits as Euro resisters, instrumental promoters and Euro enthusiasts. Euro resisters are the group who has profound oppositions to Europeanization, but they may pursue symbolic changes in domestic politics and they may give tactical concessions for the purpose of obtaining European benefits, but in the important issues confront the European politics. Instrumental promoters use norms of Europeanization to distinguish themselves from other political blocs and to position themselves as pro-European reformist forces. They may face serious political challenge from Euro resisters and their constituencies. Still, they agree to implement international institutional changes because they consider them legitimate and necessary if they are to be taken seriously by international actors on whom they depend (Subotic, 2010: 592-599). They may also implement the principles of the Europeanization for the purpose of eliminating the effects of their rivals in the domestic politics. For example during the 2000's, in Turkey, the incumbent AKP (Justice and Development Party) took advantage of Europeanization process, for the purpose of reducing the impact of the armed forces in the domestic politics (Özcan, 2008: 131-133). Finally, the Europeanization is fully accepted and supported by the Euro enthusiasts. They consisits of civil society groups and other politcal coalitions who support the Europeanization in all aspects. Their 
power and effectiveness in a state is one of the very important determinant of the course of the Europeanization in the respective state. They also confront with the Euro resisters and instrumental promoters in the domestic political area (Subotic, 2010:600). After the definition of the Europeanization and its independent variables above, in the next section, the mechanism of the Europeanization will be elaborated.

\subsection{Mechanism of Europeanization}

The mechanism of the Europeanization explains the prevailance of the EU instutions and rule of the governance in the wider international system. It is important to indicate the logical foundations of the Europeanization mechanism. There are two importany logics in the realm of the Europeanization process, namely logic of consequences and logic of appropriates (Schimmelfenning, 2005: 28). According to logic of consequences, Europeanization process proceeds through the manipulation of incentives and change of cost-benefit calculations in the third countries. In the other words, there is interests calculation and consideration whether the cost of non-executing of the EU rules and norms outweights the execution of them or not (Schimmelfenning, 2010: 8). The theories of realism, neoreailsm or neoliberalim in the international relations literature may be assessed as the product of the logic of consequences. On the other hand, logic of appropriates assumes that Europeanization is an effect of the percieved authority and legitimacy of the EU, its model of governance, or its norms and rules (Schimmelfenning, 2010: 8-9). In the case of logic of appropriates, the normative and moral consideration and intersubjective understandings has more important than the material benefits which reflects the results of the cost-benefit calculations. The normative theories or constructivists theories are more prone to adopt the logic of appropriates. According to Schimmelfenning, the Europeanization process also has two different mechanism types, namely direct and indirect. In direct mechanisms, EU takes pro-active stance and intentionally seeks to disseminate its model and rules of governance beyond its borders. In the other words, in direct mechanism, there is a deliberate EU efford to promote its governance model together with its all the functions to third countries (Schimmelfenning, 2010: 9-12). In the case of indirect mechanism, non-EU members actors take active role in the realm of adopting the European governance in their respective policies and EU generates unintented external effects (Schimmelfenning, 2010:12). According to Schimmelfenning, there are four different mechanism of Europeanization, namely, conditionality, externalization, socialization and imitation. Conditionally is a direct mechanism which EU has pro-active role. EU manipulates the calculations of cost-benefit of third countries by means of rewards such as trade agreements, accession EU as a member, accession to EU market freely or direct or indirect financial aids and by means of sanctions such as suspending or terminating the existing treaties and associations. It is important to indicate that the EU generally uses positive conditionality (rewards) rather than sanctions, in the other words, EU keeps the respective country in the waiting room until it meets the conditions. The respective country has to obey the EU's rule of governance as a condition for the 
purpose of taking advantage of EU's rewards or avoiding EU's sanctions (Schimmelfenning, 2010:1216). In the case of conditionally mechanism, the adaptation cost is very important independent variable, because for the purpose of realization of conditionality, the adaptation cost must not be higher than the international rewards (Allen, 1990: 19-21).The effectiveness of the conditionally mechanism also depends on EU reward's size and credibility. The credibility refers that the EU is less dependent and interested to agreement than the its counterpart and the counterpart must be exactly sure that only way to obtain rewards is to meet condition (Schimmelfenning, 2010:16). Börzel also states that the effectiveness of conditionality depends on EU's pressure for adaptation exerts on a target country and that target country's capacity and willingness to respond to the EU pressure, and power to resist to EU pressure (Börzel, 2010: 11-13). According to externalization mechanism, EU has indirect impact on the cost-benefit calculations of the other states. In externalization EU is not an active actor and it does not promote its model and rule of governance to third countries, but its market power which has great impact on the some counties, such as Norway, Iceland and Linchestein, forces these countries to adopt EU rules. In the other words, more interconnection and dependence to EU market, more the country adopts Europeanization (Newman, 2007: 827-830). The quasi-member states or in the other words, the member of European Economic Area (EEA) can be example of the externalization mechanism (Lehmkuhl, 2009: 14-22). Socialization stresses the direct effords of the EU on the target states for adopting its rules and rule of governanace by means of persuading them (Schimmelfenning, 2010:17). The socialization mechanism includes logic of appropriate and direct involvement of EU. In the case of socialization, rather than directly or indirectly effecting their cost-benefit calculations, EU teaches the respective countries the rules of European governance and socialization is more effective when the respective country characterizes itself as belong to Europe. The external actors adopt the EU rules if they convicted the legistimacy and appropriateness of the EU rules and EU authority (Checkel, 2000: 19). The last mechanism is imitation. The imitation mechanism is similar to socialization, but in the case of imitation, EU has not an active role and EU does not struggle to inject its rules and rule of governance to third countries. By contrast, the third counries or non-member states have an active role in realm of recognizing the EU law and rule of governance as the most appropriate solutions to their own problems (Schimmelfenning, 2010:18). The establishment of the African Union may be an example of the imitation mechanism, due to EU achivements of dealing with the politcal, economic, ethnic and sociological problems of the European Continent, the African countries regards the integration of the Europe as the most appropriate model for dealing with the same problems of the Africa and they initiated an institution which will may be a institution which is similar to EU (Bretherton, 2006: 88-89). After elaborating the Europenazation and its mechanism, in the next chapter, I will consider the scope and impact of the Europeanization in the foreign policies of Serbia and domestic policies of the Bulgaria and Romania.

\section{Europanization In the Foreing Policy of Serbia}


In this section, the back ground of EU and Serbia relationships, the barriers which prevent the effective Europeanization will be considered in line with the Serbian domestic politics and external politics.

\subsection{Backgroud of EU - Serbia Relations}

Serbia had been a federal state of the Socialist Republic of Yugoslavia until the begining of the 1990. During the Tito age, the Serbia had experienced relatively peaceful and stable period, despite historical enmity among the nations which constituted the Yugoslavia, the personel character of the Tito and cement of the idea of socialism, prevented a break down of a confrontation among these nations namely, Serbs, Croatians, Bosians, Albanians, Macedonians and Montenegronians (Seroka, 2010: 269). The demolishing of the socialism and death of the Tito generated the old enmities and an ethic civil war broke down in the Yugoslavia. The Yugoslavia had experienced the most bloodly war in the last quarter of the 20.century and the civil war which culminated in genocide, had ended with the Dayton agreement in 1995 and in Kosovo in 2000 (Savaş, 2001: 102). After the violance and civil wars of the 1990's, the Serbia realized a peaceful democratization process which culminated in democratic transition of country. In October 2000 the civil uprising of the Serbia, resulted in overthrowing of the autocratic regime of Slobodan Milosevic and a new generation of the political elits attempted to break down the legacy of the Milosevic and brought the country under the EU fold. Vojislav Kostunica, a center-right nationalist and was the leader of Democratic Party of Serbia, was elected president and Zoran Dindic, a center-left modare who was the leader of Democratic Party, elected as prime minister (Daley, 2010: 3-5). After the overthrowing of the Milosevic and establishment of a democratic regime, EU activated and initiated a great deal of assistance to new Serbian government. The EU lifted long lasting sanctions against the Serbia due to undemocratic polities of Milosevic regime and pledged 2 billions dolars for reconstruction aid and also promised 300 million aid for a year over the next seven years. The EU also offered a trade agreement that would allow tax-free Access to European markets for most Serbian exports (Subotic, 2010: 599). In November 2000, EU endorsed the Stabilization and Association Process for Serbia. The EU "democratization" platform was very inclusive, and it captured proposed reforms in the following areas: constitutional reform, parliamentary efficiency and representativeness, election integrity, public administration reform, judicial independence, police reform, and elimination of corruption. As for human rights, Serbia was to improve in the areas of media freedom, freedom of association (specifically as it relates to unhindered operations of the civil sector), access to courts and due process, anti-discrimination policies, religious freedoms, workers' rights, and rights of minorities and refugees (EU Comission, 2002). The EU has initiated its one of the most important conditionallity towards the Serbia, as indicated above the continunity of the aids were subject to Serbia's ability to meet the condition of adopting the European Governance. The EU also promote the adoption of Copenhagen politcal criteria, which include regional cooperation, good neighborly relations with enlargement 
countries and member states, and respect for international obligations, became the most important barrier of the Serbia on its way to integration with EU, because Serbia's lack of cooperation with the ICTY (International Criminal Court of Former Yugoslavia) in realm of submitting the responsiblities of the genocides and war crimes in civi war, culminated in break of the relations and even the accession negotiations in 2006 (Subotic, 2010: 600). At the begining of the 2000's, the international community has been demostrating a great sensibility and importance on ICTY's success as a bellwether of the viability of international criminal courts and international justice in general. The genocides in Rwanda, Sierra Leone, East Timor and Bosnia had a important impact on this sensibility (Kerr, 2004: 45). This attitude of the international community made cooperation with the ICTY as the EU's primary measurement of Serbia's acceptance of international justice standards (Orentlicher, 2008: 24-32). Because cooperation with the ICTY was a measurable indicator, the number of suspects arrested and transferred to The Hague and the number of documents and testimonies sent could all be classified, systematized, and easily counted, it soon became the major, if not the only, EU measurement of how far along Serbia was in adopting the idea of addressing crimes from its recent past. This, in turn, then became shorthand for Serbia's readiness to Europeanize (Klaus, 2001: 420). The EU linked all the rewards of its conditionality such as financial aid, dept relief, direct investment, trade preferences, and EU membership to Serbia's cooperation with the ICTY (McMahon, 2008: 412418). Even though Serbia has initiated many reforms in the realm of economy, fiscal and monetary politics, trade, customs, taxes, police and army reform for the purpose of establishing an European governance, its problematic cooperation with the ICTY has culminated in end of Europeanization process. Due to high cost of the cooperation with the ICTY in the domestic politic, the Serbian policy makers chose the preference of not cooperate with the ICTY, even the EU conditionally mechanism could not create eligible incentives for cooperation because the cost was too high and it might be result in confrontation with its own identitty and could cause instability in domestic politics. The next section the domestic factors of the Serbia will be elaborated which have great impacts in its foreign policy.

\subsection{Domestic Politics of Serbia and ICTY}

The new Serbian government had faced a serious problem after the overturning of the Milosevic in October 2000, the tansitional govenrment was unable to deal with the issue of Milosevic and other war crimes committed during the civil war (McMahon, 2008: 446). As indicated above the coalition of transitional government had already some problems at the begining of the transition period. This disagreement increased by means of first government crisis erupted over the question of what to do with Milosevic (Subotic, 2010: 601). The president Kostunica and his Democratic Serbian Party, were opposed putting the Milosevic on trial and supported an amnesty, on the other hand prime minister Dindic and his Democratic Party, advocated investigating Milosevic for abuses of power, but not war crimes, and proceeding with arrest and a domestic trial (Subotic, 2010: 603). There are two 
important points in the Serbian politics, first the reluctance of the president Kostunica to extradite Milosevic, culminated in suspension of the all the financial aids of the EU and USA, for the reconstruction of the Serbia, and on the other hand, this disagreement between the Dindic and Kostunica created a domestic political conflict in the Serbia. It is important to emphasize that both Kostunica and Dindic rejected the investigation of the war crimes, as indicated above Dindic was supporting the putting Milosevic on trial on the issues of abuses of power and he also advocated a domestic trial rather than the ICTY. This domestic conflict increased when prime minister Dindic provided the arrest of Milosevic for corruption and abuse of power. The Milosevic was arrested in a Belgrade prison on 31 March 2001 when the president Kostunica was out of country on a state visit and unable to intervene or block arrest operation (Subotic, 2010: 608). After that Milosevic secretively transfered to the Hague on 28 June 2001, in an operation coordinated by Dindic (Kalus, 2001: 478). Dindic might changed his policy of a domestic trial for the purpose of increasing his legistimacy in international politics and providing the financial aids of the international donors again. These developments were ended by the assassination of Dindic in March 2003. The assassination was adopted by the "Red Berets", which was a notorious paramilitary unit, and they indicated that Dindic was assissinated for the purpose of stopping the Hague investigations and extraditions (Subotic, 2010: 608). Dindic's assassination was a pivotal moment in Serbia's transition. His death left a huge power vacuum, which was immediately filled by Koštunica's Democratic Party of Serbia (DSS) and by the extreme nationalist Serbian Radical Party (SRS).The first post- Dindic elections indicated a strong normalization and relativization of war crimes and their perpetrators, who made an open comeback into mainstream politics (Subotic, 2010: 609). The assassination was culminated in great deviations of Serbian politics on its path to Europeanization, because the only facilitator factor, Dindic, was assassinated and this trajic end regarded as a serious reason for non compliance with the ICTY, by the Serbian policy makers. According to president Kostunica, the Hague investigations is not only unnnecessary, but also outright counterproductive for Serbia and dangerous for its leaders (Subotic, 2010: 610-611). After the end of the December 2003 elections the reformists had weaked due to elections and Serbian government passed a law to fund and legally faciliate the defence of indicted war criminals before ICTY (McMahon, 2008: 657). But ICTY had continued its investigations on war crimes and required four Serbian generals due to their crimes against the humanity during the Serbia's war in Kosovo in 1999. These indicments presented a serious problem for Serbia because they were stil on duty in Serbian Armed Forces and Serbian government did not submit them to ICTY nearly one year (McMahon, 2008: 659). But the Serbian politics had begun to change after the 2004. Because Serbia was isolating from the continental politics and all the Balkan countries had begun to integrate with the EU, and all the financial aids and incentives were cut due to non compliance of the Serbia with the ICTY (Subotic, 2010: 614). Besides them, the most important issue which provided the transformations in Serbian politics was the issue of Kosovo and Montenegro, which Serbia desired to 
participate in the negotiations related to future of these countries (Subotic, 2010: 615). As a consequence of these developments, the Serbian government designed a policy of "voluntary surreders" (Subotic, 2010: 615). According to this strategy, the action to surrender of the war criminals to ICTY had injected the Serbian public as pariotic duty, Both Serbian government and Serbian Orthodox Church declared that Serbia was suffering because of a few individuals, whose patriotic duty was to surreder so Serbia could move (Subotic, 2010: 616). Then, the Serbian government passed the Law on the Rights of Indictees in the Custody of the International Criminal Tribunal and Members of Their Families, which provided financial assistance for the war criminals' families (Subotic, 2010: 622). This strategy was clearly aimed at the domestic political audience. The Serbian people were told only that these suspects were leaving for The Hague because it was the international community's "requirement," or as an act of patriotic duty. They were repeatedly told by their government that these transfers were opening up doors for Serbia to join the EU, an issue that the government of Vojislav Koštunica made a centerpiece of the coming election campaign (Katie, 2006: 41-45). They were not once informed for what crimes these individuals were indicted, how these crimes came about, who the victims were, what the scope of abuse was, or any other details regarding the substance of indictments. Instead, masked in the guise of voluntary surrenders, dealing with the past was repackaged as acts of patriotism for which the state was grateful. And so the stepped-up pressure from the ICTY and other international actors did not translate into any substantial changes in Serbian understanding of its own history, nor in any attempt to address past abuses in a systematic way (Subotic, 2010: 620). In the other words, the Serbian politics were not culminated in the transformation of the Serbians intersubjective understandings in the realm of the Bosian and Kosova, which they regarded the reason of the wars as the other nations and they regarded the war crimes in these wars as the action of selfdefence of the Serbian people. There was no identity transformation by means of Europeanization, rather there was an policy transformations due to national interests. After the acception of this "voluntary surrender" strategy, the Serbian government submit its four generals to ICTY, and the rewards of this submission came immediately from the EU. The EU approved a positive feasibility study and the go-ahead to negotiate a Stabilization and Association Agreement (SAA) on 12 April 2005, it was necessary step towards the negotiations for EU membership (Katie, 2006: 46). The improved cooperation with the ICTY also gave Serbia much needed international financial boost in investment. Furthermore, it eased the pressure on the Serbian government, which hoped the ICTY would finally leave Serbia to its internal affairs and forget that the two major suspects, Radovan Karadžić and Ratko Mladić, were still very much fugitives from justice, on the other hand, Serbian government did nothing for the investigating war crimes inside its national borders. Both Serbian police and ministry of internal affairs did not assist the ICTY for collection of evidences (Subotic, 2010: 629). Radovan Karadžić and Ratko Mladić were the most important war criminals of the Bosian War, but they were also regarded as national heros by the most of the Serbian public and their 
submission to ICTY, might create a great outrages in the dometsic policies of the Serbia. As indicated above, in Serbia there was no transformation in the intersubjective understandings of the people and to surreder to ICTY was stil regarded as a patronic duty rather than compliance to international law. And Serbia had not submit Miladic for a long time to ICTY and the Serbian government had pursued to reject the existance of the Miladic and Karadzic in the Serbian territory, but in 31 May 2011, it submitted them to ICTY due to high pressures and isolation threats from the international community (Subotic, 2010: 629). The EU and Serbia relations on the way of integration has continued after that. It is important to consider the reasons of why Serbia's Europeaniztion process delayed untill that date in line with the principles of independent variables of Europenization. The rest of this section will elaborate them.

\subsection{Absence of European Idea}

As indicated above, Accountability for human rights, in other words, became a trading currency between local elites and the EU and other international actors, de facto removing the substantive issue of addressing past wrongs from the public debate. The Serbian government used international justice and ICTY as a foil to send signals to the domestic audience that nothing significant would change, that the grand narrative of Serbia's victimization and the need for its vindication would continue, that in fact by trading these suspects one by one, Serbia would achieve great international awards and the most coveted prize being negotiations for EU accession. In other words, this strategy has allowed Serbia to go through the motions of complying with European institutional demands while in fact rejecting a profound social transformation Europeanization requires. In this respect, the EU has a great mistakes, the conditionality mechanism of the EU, manipulated in line with only compliance of the Serbia with the ICTY requirements, there was no actual conditionality for the purpose of dealing with the identitty and intersubjective understanding differences and diversities between the EU and Serbia (Subotic, 2010: 634-644). The Serbian public largely refused to believe that Serbians have committed war crimes, and they blamed other nations and ethnic groups for starting the wars; they also distrusted international community and by proxy international justice institutions, mostly the ICTY (Ramet, 2002: 23-34). On the other hand, Milosevic had ruled the country with a large public consensus for a long time, in the other words, Milosevic and its political preferences had been supported by the most of the Serbians for a long time and the victimization myth of Serbians after the end of the Yugoslavia had believed by the large public sections for a long time (Gordy, 2005: 58-62). Consequently, societal participation in the criminal past was widespread and multilayered. There were participants of political elites, the church, intelligent service, and the military who remained in power after the transition and actively blocked transitional justice projects because of their own responsibility in inciting or conducting them. Then there was literal, physical participation by direct perpetrators, troops and paramilitaries, who now led civilian lives. Finally, and most intractably, there was "psychological participation" of a significant majority of 
the population who approved of the nationalist project in its general terms (Gordy, 2005: 88). Another important issue is that, the Serbian public regarded the civil war and even the genocides and war crimes as a consequence of an international war and self-defence of the Serbia, in the other words, according to Serbian public consensus, Serbia was in war with the enemies and it was struggling to defend itself against them. This point of view has great contradictions with the general idea of the European community in particular, international community in general (Fletcher\&Weinstein, 2008: 580). And even more significantly, Serbian elits displayed strong ideological reluctance to Europeanize, becuse these elits and most of the Serbian public had believed a narrative that Europe had a significant role in the Yugoslav breakup and wars that ensued, in the other words, there was a great suspections in the minds of Serbians in the field of reliability of the Europen Union, they considered that the EU sacrified the Yugoslavia for its interests by supporting the independence of the former Yugoslav Republics of Slovenia, Croatia, Bosnia and Herzegovina, Macedonia and the most dramatically and recently Kosovo and Montenegro (Gordy, 2005: 102). Consequently, there was no consensus between the Serbia and EU in the realm of the dealing with the requirements of the ICTY. The conditionality and other Europeaniztion mechanism had failed to create a European identity in the Serbia due to nationalist factors and high distrust towards the EU in Serbian public and elit and EU's disability to manipulate the its conditionality in line with the identity transformation in Serbia.

\subsection{Power of Old Regime Spoilers}

The other obstacle of Europeanization in Serbia and its refusal to comply with requirements of the ICTY, is presence of the old Milosevic regime's members with the military, police, secret service and public service. The Serbian governments after the overturning of the Milosevic has not provided the absolute monopoly over the use of force due to their existance in the important places in the government (Subotic, 2010: 647). Consequently, this political structure blocked a "clean break" with the Milosevic period and due to political fragmentation in the Serbian domestic politics, all the governments had to make coalition or inlude their coalitions the pro-Milosevic supporter parties such as Radical Party, and this domestic political reality, together with a coup possiblity of the army which maintains many Milosevic supporters, created a reluctance in all Serbian governments in the realm of compliance with the ICTY requirements (Gordy, 2005: 109). On the other hand, many members of the old regime's paramilitary group leaders, integrated officially or semiofficially into the police force. In addittion, many of paramilitaries has taken part in the regular organized crime after the war and they had large Networks of consprirators across the region and they were highly motivated to protect themselfes at all costs against the ICTY, as they proved in the assassination of the Dindic (Gordy, 2005: 110-113). This structural position of the domestic politics, has prevented the acceptance of the European Union demands, in Serbian political area, because the adaption of EU demands was more costly than the refusing them (Gordy, 2005: 114). 


\subsection{Elite Strategies}

In the section one, three types of elits, namely, Euro resisters, instrumental promoters and Euro enthusiast, were indicated. In Serbian domestic politics, conservative parties such as Kostunica's DDC Party and Radical Party and Socialist-Communist Party constitutes the Euro-resisters. They rejected the cooperation with the ICTY in line with the international law and they regards the resistance against the investigation of Milosevic period's war crimes as a patrionic mission (Subotic, 2010: 648). They support the nationalist policies and due to non transformed Serbian identity sturcture, this continuing resistance scores them valuable domestic politcal points and secure their unchallenged place on the right of the political spectrum (Ramet, 2002: 34). In the case of instrumental promoters, Dindic's Democratic Party and after his assassination Tadic's party constitutes this elit group. They illustrate a tactic support for the ICTY investigations for the purpose of strenghtening their poistion against their rivals in both international and domestic arena, but as a matter of in fact the real aim of them, was the benefiting form the incentives of the EU and other international donors, rather than the providing a comprehensive transformation in Serbian identities and intersubjective understandings, in the other words, the Europeanization process was regarded as a tool rather than an aim (Subotic, 2010: 649). The last group is Euro enthusiast which was consists of civil organizations and civil societies, was very weak in Serbian domestic politics. They are real supporters of the Europeanization process but due to decades of authorative administrations, their political, social and economic power was very restricted, on the other hand the EU did not supply them sufficently in the Serbia untill the 2010 (Subotic, 2010: 650). In sum, if one takes into consideration the structure of elit groups and the balance of power among them, it is obvious that the political circumstances in Serbia was not eligible for effective Europeanization. The next section two other Balkan countries namely, Bulgaria and Romania will be eloborated in the realm of Europeanization process in their domestic politics.

\section{Europeanization in Domestic Politics of Bulgaria and Romania}

In this section, the impact of the Europeanization in the case of domestic politics of the Bulgaria and Romania will be elaborated. Bulgaria and Romania has been driving towards the Europe since the 19th century (only exceptional period was the communism age). After the demolishing of the Soviet Union in particular, the communism in general, the aspirations of both countries towards the Europeaness did not automatically translate into ability to change and conform to the European standarts. The Romania and Bulgaria has suffered from the politcal instability and lack of politcal will, despite public consensus across party lines over EU accession, led the to relative slower economic and politcal reforms and poorer record of implementation of acquis (European Body of Law) (Dimitriova\&Dragneva, 2001: 82). In the other words, both Bulgaria and Romania have not accomplished the implementation of the European governance, despite they have adopted EU law in their legistation procedures. The most important reason of this failure is backtracting of the political 
elits and their lack of political will who have most benefited from large scale endemic corruption. Thus, these legislative and judicial reforms have not culminated in consolidating of the effective democracy and European governance (Racovita, 2009: 28-33). The enlargemenet-led Europeanization which occured through the policy of conditionality, has promoted the democratic and liberal elements of the Romanian and Bulgarian government, but the EU's ability to penetrate domestic institutions is not perfect due to high level of corruption and organized crime Networks (Dimitriova \& Dragneva, 2001: 83). The Copenhagen criterias which is the precondition for the EU membership, stipulates rule of law, transparency and seperation powers. The corruption in legislative bodies reduces accountability and representation, corruption in the judiciary suspends the rule of law, corruption in the public administration results in unequal provision of services (Dimitriova, 2003: 171-172). In the other words, the corruption prevents the adoption of the Copenhagen criterias and it became subjected to EU monitoring mechanism in case of Romania and Bulgaria due to high level of corruption and lack of political will to prevent it (Dimitriova \& Dragneva, 2001: 85). As a matter of in fact the corruption issue has became the most important issue of the EU conditionality mechanism in Romania and Bulgaria as it focused on the compliance of the ICTY in the case of Serbia. It is important to make the defition of the corruption, according to Levitsky it may defined as " any conduct or behaviour in relation to persons entrusted with the responsibilities in public Office which violates their duties as public officials and which is aimed at obtaining undue gratification of any kind for themselves or for others" (Levitsky, 2003: 432). In CEE (Central and East European Countries) the corruption had been a problem due to communist autocracy, but it has continued and prevailed after the 1989 due to moral chaos of demolishing of the communist regimes and opportunities for corruption created by the privatization and transition period's circumstances (Levin \& Satarov, 2000: 113-132). In Romania and Bulgaria, the level of this coruuption has very higher than the other CEE and due to lack of political will (because in both countires, the communist regimes elits are still exist in the public administration and they have overwhelming impacts on the decision- making process) the EU's effords to deal with this corruption has not culminated in a sufficent achievement (Levitsky, 2003: 441). As indicated in the Serbian case these countries have Euro resisters, instrumental promoters and Euro enthusiasts. In Serbia case, as indicated above, the conditionality mechanism has failed due to powerful impact of the Euro resisters who directly oppose to European integration. But in Romania and Bulgaria the situation is different. In these countries both public and political elits demonstrates a great support to European integration and both of them have overwhelming instrumental promoters but despite they both support the integration for the purpose of pursuing their interests, these instrumental promoters have different aims, the public support the European integration, due to terminate the corruption and to provide the general welfare, the politcal elits support the European integration for the purpose of taking advantage of European finacial and economic aids which they use these aid for their own interests by means of high level of corruption (Campos \& Fidrmuc, 2003: 23-25). Thus, in Bulgaria and Romania, the 
legislative process initiaded by the governments of the both states due to conditionality mechanism, but the implementation of these reforms did not initiated sufficently. In the other words, both countries accomplished establisment of formal democracy which includes the formal reforms on the paper, but they could not accomplished the effective democracy which emphasises the spread of the democratic practices troughout society and terminating of the all kinds of patrimonialism and clientelism (Heller, 2000: 490-495).

\subsection{Variables of the EU's Efficient Democracy in Bulgaria and Romania}

In this study, some dependent variables will be selected for the purpose of meansuring the domestic impact of the Europeanization in Romania and Bulgaria. A system of causal chain which consists of one independent varible, two intervening variable and five dependent variables. The independent varible is the impact of the Europeanization in domestic politics of Romania and Bulgaria, the frist intervening varible is level of efficient democracy, the second intervening varible is level of corruption in these countries. Because as indicated above, corruption is the most important reason of the failure of the rule of law, transparency and seperation of power which are the main pillars of the effective democracy and European governance. The dependent variables are political competitiveness, democratic accoundability, quality of bureaucracy, law and order and lastly government stability. The hypothesis that will be used are,

1. The more corruption in a country, less political competitiveness in a country,

2. The more corruption in a country, less democratic accoundability in a country,

3. The more corruption in a country, less quality of bureaucracy in a country,

4. The more corruption in a country, less law and order in a country,

5. The more corruption in a country, less government stabiility in a country,

And for the main thesis, more corruption in a country, less effective democracy in a country, less Europenization in domestic politic of a country in a country. Some degree of the selection bias due to lack of the sufficent empirical data is accepted. First the corruption levels of Romania and Bulgaria will be elaborated and then they will be compared with the levels of other dependent variables. The dependency between the corruption and other dependent variables will be analysed. And then the main reason of the failure of European conditionality mechanism in particular, failure of the effective democracy and Europeanization in general as the backtracting strategy in Romania and artifical legislation process of Bulgaria will be elaborated.

Table 1: Corruption Level of Romania and Bulgaria Between 1998-2011 


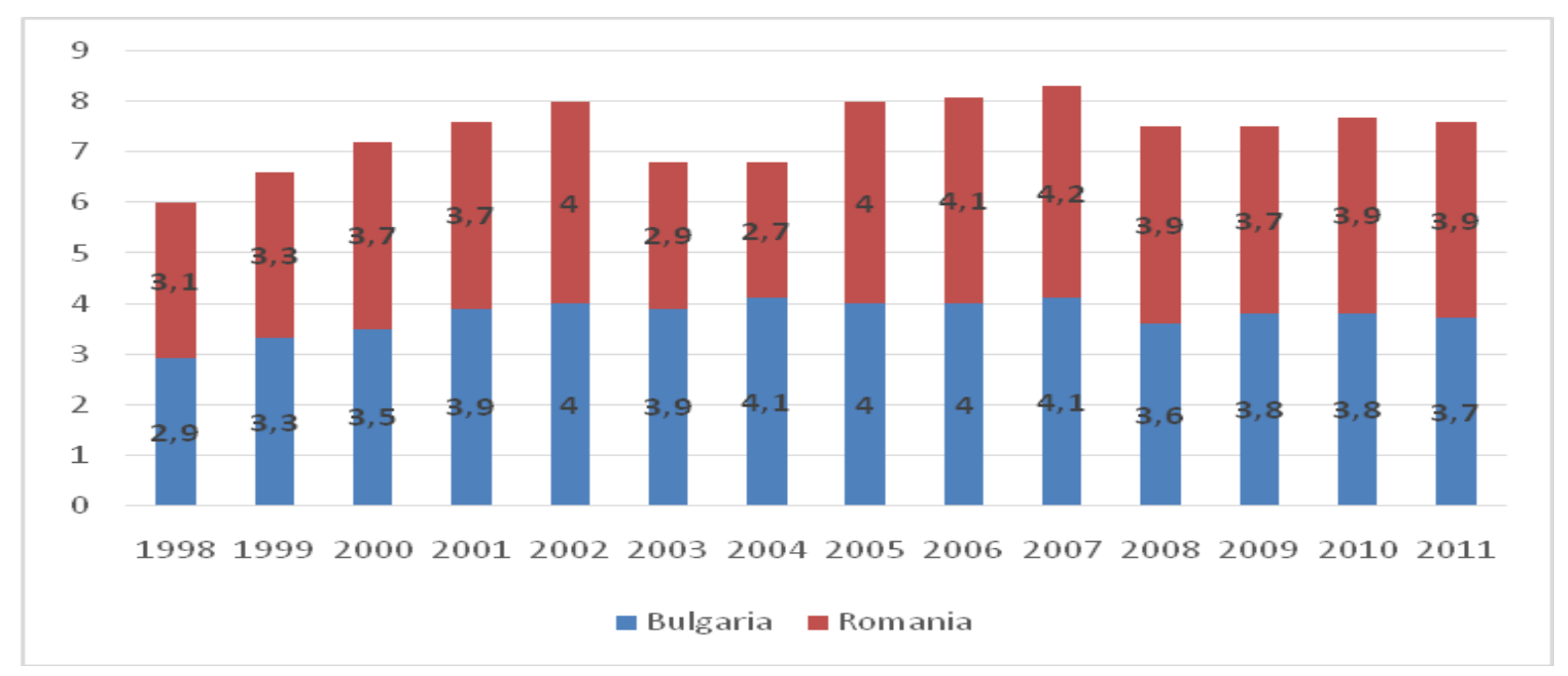

Department of Economics, University of Aarhus, TI Indext of Corruption 1995-2011, (04.11.2018) http://www.martin.paldam.dk/Papers/Corruption/TI-index.pdf

In the Table 1, the number of " 6 " is equavalent to highest corruption level and number " 0 " is equavalent to lowest corruption level. As the indicated in the Table 1 Romania and Bulgaria have a high degree of corruption not only in the pre-accession period, but also aftermath of the accession despite the empowerment of the high conditionality mechanism by the EU, for the purpose of terminating the corruption. In the Bulgaria 1997 elections followed the far reaching economic crisis, and brought a centre right government with a reformist agenda. However early steps to introduce good governance mechanisms (enacting several anti-crime and corruption laws and amending the Privatization Act to improve transparency) enhancing institutional efficiency and transparency diluted in a series of corruption scandals by the end of the Kostov's government mandate (Fish \& Brooks, 2005: 69-77). In 2001 election a newly established party with an anti-corruption plarform won the election (GERB), but by 2005 this government was also embroiled in several corruption scandals (among which the less than transparent privatization of Bulgartabac) and despite successfully concluding the EU chapter negotiations, it was penalized by the electorate. As successive governments promised change, achieved little and by the end of their mandate had more to show in terms of corruption scandals that anti-corruption measures, the average Bulgarian seems to have given up on the ability of the politicians to deliver and doubts there is political will to address corruption (Levitsky, 2003: 449). In Romania despite several government changes due to corruption scandals, and despite all the creation of several institutions for anti-corruption such as CNSAS, DNA, NAP etc, as the Table 1 Demonstares there has not a significant transformation in the range of endemic corruption. If we take into consideration the other dependent variables of the effective democracy which are correlated with the coruuption level, both of the countries has not a remarkable transfromations.

Table 2: Bulgarian Efective Democracy Measures 


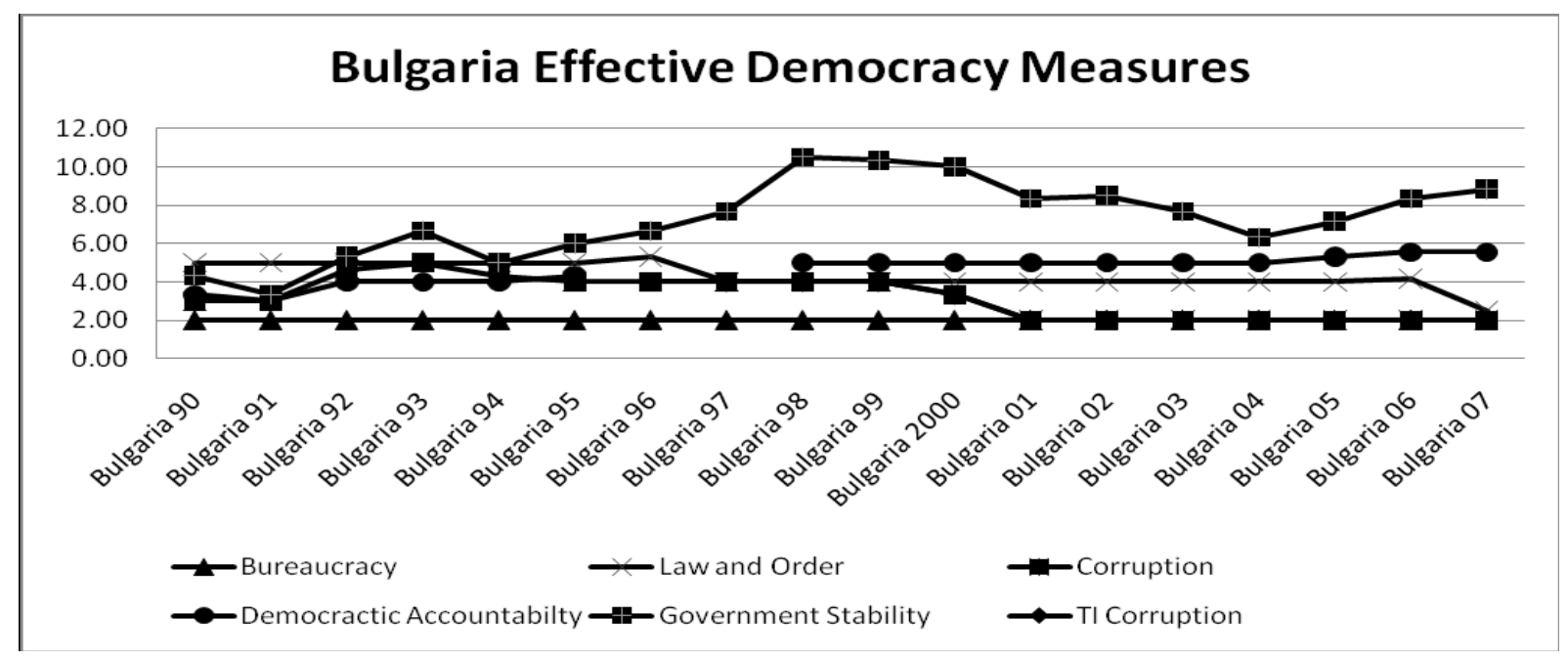

Department of Economics, University of Aarhus, TI Indext of Corruption 1995-2011, (04.11.2018) http://www.martin.paldam.dk/Papers/Corruption/TI-index.pdf

Table 3: Romanian Efective Democracy Measures

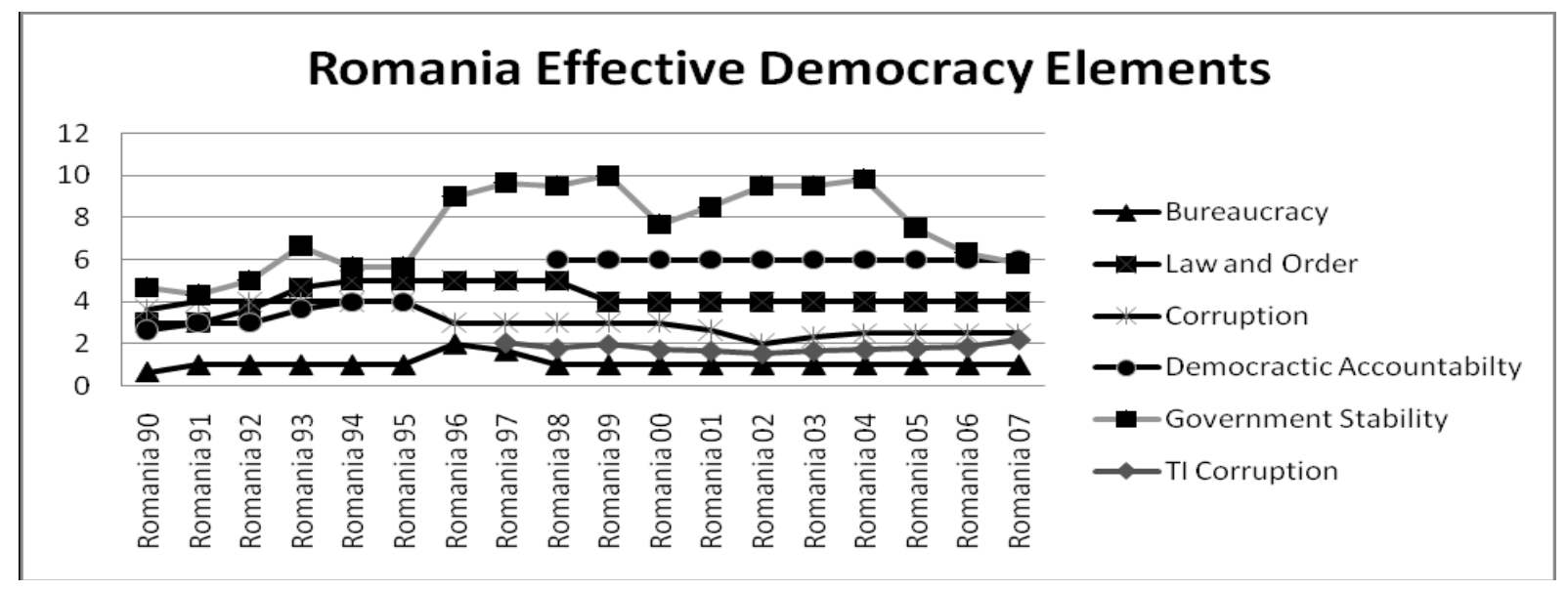

Department of Economics, University of Aarhus, TI Indext of Corruption 1995-2011, (04.11.2018) http://www.martin.paldam.dk/Papers/Corruption/TI-index.pdf

As indicated in Table 2 and Table 3 and if one compares the data in Table 1, it is obvious that the corruption levels and other dependent variables of the efficent democracy are correlated and consequently, the impact of the Europeanization may be assessed through the level of the corruption in these countries. In the other words, level of the corruption in these countries not only reduce the Europeanization in these countries, but also prevent the consolidating of an efficent democracy in these countries (Racovita, 2009: 36). The EU had made several critisms to Bulgaria and Romania in pre-accession period by means of the annual reports of the Commissions and it conditioned the accession to EU to terminating the corruption and making reforms for endevaouring the corruption (Smilov, 2006: 314-317). The EU also has thraetened the Bulgaria and Romania with the freezing the accession negotiations which is the most important tool of the conditionality mechanism, due to lack of fight against the corruption in many times (Fish \& Brooks, 2005:76). In response to EU's criticisms, 
the two countries opted for different strategies though aiming for similar outcomes: protecting the status quo while simulating adoption of EU standards. Romania created bodies, egencies, institutions (as indicated above) while Bulgaria put in places strategies and make legislative reforms (Racovita, 2009: 38). In Bulgaria legislative reform advanced in small installments followed by amendments to improve the scope of reform or its transparency. In Romania projects of law adopted to meet EU standards were soon amended under pretext of improving efficiency while in fact restraining the scope and power of created bodies to tackle corruption (Racovita, 2009: 42). In Bulgaria several laws were enacted ensuring the independence of the judiciary or strategies of tackling corruption (2002 and 2004) and organized crime, such as the "National strategy for combating organized crime" (1998) and anticorruption law of 2006. But despite these judicial progression, the implementation of the these newly acted laws has had poor records and it critised by EU and many other international organizations such as Transparency International.(see Table 4) In the case of Romania the instrumental promoters of political elits, seek to amend or dilute the legislation through formal means, in the other words they made backtracting which means amendments that dilute the reforms, annulment of government ordinances by Parliment, or any other measure with the purpose of diminishing the capacity and scope of reforms. Consequently, despite the establishment of many anti-corruption institutional and inspection mechanism, due to political pressure and dependence of them, it made little to no progress in implementing the legislative reforms. It is so important to indiicate that backtracting occured in $\% 82$ of the reform initiaition in Romania, with only \%18 keeping in their ground. (see Table 5). Thus, the gap widened between formal rules and the situation on the ground or in other words, between the real country and the legal country (Smilov, 2006:256-367).

Table 4: Bulgarian Lack of Implrmantation the Anti-Corruption Reforms.

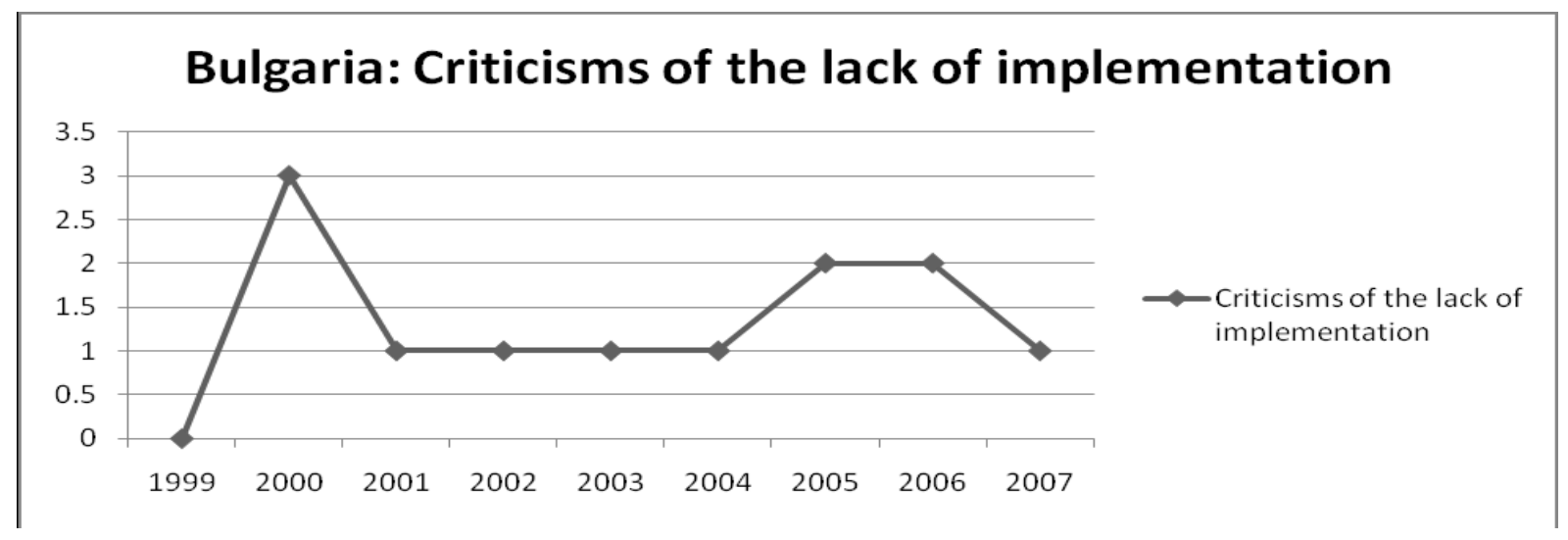

Galev, Todor, "Bulgarian Lack of Implementation the Anti-Corruption Reforms”.(12.11.2018) 
http://books.google.com.tr/books?id=fhJgIXkcdaIC\&pg=PA33\&dq=Bulgarian+Lack+of+Implementation+the+ AntiCorruption+Reforms.\&hl=tr\&sa=X\&ei=JVEVOmTN8i7UZjYgvAP\&ved=0CDcQ6AEwBA\#v=onepage\&q $=$ Bulgarian\%20Lack\%20of\%20Implementation\%20the\%20Anti-Corruption\%20Reforms.\&f=false

Table 5: Backtracting in Romania Untill 2011

\section{Romania: Strategy of Backtracking}

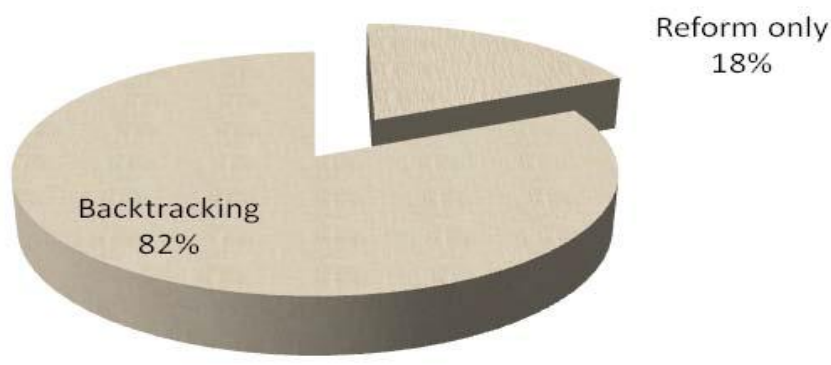

OECD, Asset Decrataion for Public Officers, a Tool of Corruption, (12.11.2018)

http://books.google.com.tr/books?id=0eOfxvAHi9wC\&pg=PA122\&dq=corruption+Romania+Until+2 011.+,\&hl=tr\&sa $=X \&$ ei $=3 \mathrm{mCEVLqPO} 4 \mathrm{rzUuasg} \_\mathrm{gE} \& \mathrm{ved}=0 \mathrm{CCEQ} 6 \mathrm{AEwAQ} \# \mathrm{v}=$ onepage $\& \mathrm{q}=$ corrupti on\%20Romania\%20Until\%202011.\%20\%2C\&f=false

In sum, according to empirical datas above, it can be assumed that despite the powerful EU existance of conditionality mechanism in both Bulgaria and Romania on the way to establishment of effective democracy and consequently terminating corruptions, these effords were culminated in failure. In Bulgaria the problem of poorly implementation of reforms on the ground and in Romania dilution of the reforms by means of other legislative regulations, namely backtracting, the impact of the Europeanization in these countries could not provide an effective European governance.

\section{Conclusion}

The conditionality mechanism and its most important tool of membership, has provided efficient democracy and great domestic transformation in the domestic and external policies of many post-communist countries in the East Europe and Balkans. But this achievement depends on the existance of the eligible actors and political elits' preferences of the respective country. The existance of the Euro resisters who are mainly spoils of the old regime and their relative power in the decision making process of the respective country and the high cost of the adaptation process on the interests of this group may prevent the impact and transformative power of Europeanization in this country as happened in Serbia case. As indicated above, the high incentives of both EU and other international actors, the Serbian elits who maintains many nationalist old regimes supporters, despite the membership rewards, has prevented the compliance of the country with the international law for a long 
time due to high level cost of the compliance. On the other hand, lack of Euro resisters and the existance of the instrumental promoters in the political elit of respective country is not sufficent for transformation in the domestic politics of the respective country as happened in the case of Bulgaria and Romania. The intension of these elits is also important, for effective Europenaization, they mas keep away from the corruption and backtracting strategy. In the other words, they must adopt the acquis of EU for the purpose of promoting the effective democracy rather than the taking advantage of EU's financial and political aids and incentives for their personal interests. According to my point of view, it may be achieved by means of a power and effective domestic inspection mechanism which can provide the transformation. Thus this effective domestic inspection mechanism may be depends on the existance of the Euro enthusiast which consists of mainly from the civil public organizations. If one takes into consideration the three of the cases, their common feature is lack of or weakness of the domestic civil public organizations. These domestic civil public organizations not only pursue the general welfare of the public, but also they provide the non-official inspection of the reforms on the ground, if they gained sufficient power, they may manipulate the government policies and election conclusions according to level of corruption. Thus, EU should provide more finacial and political aids to these domestic civil public organizations, in line with official aids to governments. It is a indispensible obligation on the way of establishing an effective democracy.

\section{REFERENCES}

ACEMOĞLU, Daron (2013), Why the Nations Fail: The Origins of Power, Prosperity and Poverty, New York: Profile Books.

ALLEN, David (1990), "Western Europe's Presence in the Contempolrary International Arena", Review of International Studies, 16(1):19-39.

BEHNKE, Adreas (2006), “The Three Faces of Political Securitization”, Journal of International Relations Development, 9(1): 62-69.

BÖRZEL, Tanja (2010), “The Transformative Power of Europe Reloaded”, Journal of Berlin Freie University, 11(1): 10-22.

BRETHERTON, Chris (2006), The European Union as a Global Actor, London: Orbie Publications.

CAMPOS, F. Nauro \& Jan FIDRMUC (2003), Political Economy of Transition and Development: Institutions, Politics and Policies, Dortrech: Kluwer Academic Publishers.

CHECKEL, Jeffrey (2000), "Why Comply? Social Learning and European Identity Change”, Journal of International Organization, 21(1): 12-43.

DALEY, Suzanne (2000.10.10), "European Union Greets Yugoslav Government”, The New York Times: 4-5. 
DIMITRIOVA, Antoaneta vd. (2001). "Bulgarian Roads to EU: Process, Problems and Perspectives", Perspectives on the European Politics, 25(1): 79-104.

DIMITRIOVA, Antoaneta (2002). "Enlargement, Institution Building and the EU's Administrative Capacity Requirement”, West European Politics, 25(4): 171-190.

EROĞUL, Cem (2008), Çağdaş Devlet Düzenleri, Ankara: Kırlangıç Basımevi.

EUROPEAN COMMISSION (2002.04.04), "Federal Republic of Yugoslavia: Stabilization and Association Report," (2018.10.10), https://eur-lex.europa.eu/legalcontent/GA/TXT/?uri=OJ:C:2002:163:TOC

FARREL, Meister (2007). "From EU Model to External Policy? Promoting Regional Integration in the Rest of the World, in Meunier", Making History. European Integration and Institutional Change at Fifty, (Ed. Samule McNamara),Oxford: Oxford University Press.

FISH, M. Steven \& Ruben S. BROOKS (2005), "Bulgarian democracy's organizational weapon." East European Constitutional Review, 9(1): 828-842.

FLETCHER, E. Laurel vd. (2008), "Violence and Social Repair: Rethinking the Contribution of Justice to Reconciliation," Human Rights Quarterly, 24(3): 573-639.

GORDY, Eric (2005), Postwar Guilt and Responsibility in Serbia: The Effort to Confront It and the Effort to Avoid it, Seattle: University of Washington Press.

GRUGEL, B. Jean (2004), "New Regionalism and Modes of Governance Comparing US and EU Strategies in Latin America", European Journal of International Relations, 10(4): 600-646.

HELLER, Patrick (2000), “Degrees of Democracy: Some Comparative Lessons from Bulgaria”, World Politics, 52(4): 484-519.

JOHNSON, Iain (2001), “Treating International Institutions as Social Enviroments”, International Studies Quartely, 45(1): 485-522.

KANT, Immanuel (1960). Ebedi Barış Üzerine Felsefi Deneme, (Çev.: Yavuz ABADAN \& Sehal MERAY), Ankara: Ajans Türk Matbaası Yayınları.

KEOHANE, Robert (1993), Ideas and Foreign Policy: Beliefs, Institutions, and Political Change, New York: Cornell University Press.

KERR, Rachel (2004), The International Criminal Tribunal for the Former Yugoslavia: An Exercise in Law, Politics, and Diplomacy, Oxford: Oxford University Press.

LAVENEX, Sandra \& Frank SCHIMMELFENNING (2009). "EU Rules Beyond EU Borders: Theorizing External Governance in European Politics", Journal of European Public Policy, 16 (6): 755-802. 
LEHMKUH, David (2009), "Switzerland's Flexible Integration in the EU", Zeitschrift für Politikwissenschaft, 15(4): 43-87.

LEVIN, Mark \& Georgy SATAROV (2000), Satarov. "Corruption and institutions in Russia." European Journal of Political Economy, 16(1): 113-132.

LEVITSKY, Steven (1997), "Democracy with Adjectives: Conceptual Innovation in Comparative Research", World Politic, 48(1): 437-485.

MAJONE, Giandomenico (2008), Civilian Power in the World? Instruments and Objectives in European Union External Policies, London: Aldershot Press.

McMAHON, C. Patrice (2008), “The ICTY's Impact on Serbia: Judicial Romanticism Meets Network Politics," Human Rights Quarterly, 30(2): 412-435.

NEWMAN, Bach (2007), “The European Regulatory State and Global Public Policy.: Micro Institutions and Macro Influence”, Journal of European Public Policy, 14(1): 827-846.

ORENTLICHER, Diane F. (2008), "Shrinking the Space for Denial: The Impact of the ICTY in Serbia”, Open Society Institute Journal, 23(2): 21-35.

OWEN, M. John (1994), "How Liberalism Produces Democratic Peace”, International Security, 19(2): $87-125$.

OZCAN, Mesut (2008), Harmonizing Foreign Policy; Turkey, the Eu and Middle East, London: Ashgate Publishing.

RACOVITA, Mihaela (2009), "Europeanization and Effective Democracy in Romania and Bulgaria", Journal of Romanian Academic Society, 23(2): 28-33.

RADELLI, M. Claudio \& Kevin FEATHERSTONE (2003), The Europeanization of Public Policy, Oxford: Oxford University Press.

RAMET, P. Sabrina (2002), Balkan Babel: The Disintegration of Yugoslavia from the Death of Tito to the Fall of Milošević, Westview: Boulder CO.

SAVAŞ, Hüseyin (2001). “Dünü ve Bugünüyle Kosova Sorunu”, Cumhuriyet Üniversitesi Sosyal Bilimler Dergisi, 25(1): 99-123.

SCHIMMELFENNING, Frank (2010), "Europeanization Beyond the Member States", Comparative and International Studies Journal, 3(2): 2-35.

SCHIMMELFENNING, Frank (2005), The Europeanization of the Cenral and Eastern Europe, New York: Cornell University Press.

SEROKA, James (1978), "Prospects for Stability in Post-Tito Yugoslavia”, Slavic Review, 37(2): 250275. 
SMILOV, D. (2006), EU Enlargement and the Constitutional Principle of Judicial Independence, Dordrecht: Klaus Academic Press.

SUBOTIC, Jelena (2010), "Explaning Difficult States", Journal of East European Politics and Societies, 7(1): 9-52.

TODOROVIC, Rayner \& Alex Gordon (2011.07.14), "Radovan Karadzic ally General Ratko Mladic will 'commit suicide rather than face justice'", The Telegraph: 13.

VACHUDOVA, Anna Milada (2005), Europe Undivided: Democracy, Leverage, and Integration after the Communism, Oxford: Oxford University Press.

VON BEYME, Klaus (2001), “Regime Transition and Recruitment of Elites in Eastern Europe”, Governance, 6(3): 611-645.

WALLACE, William (1999), "Europe After the Cold War: Interstate Order or Post-Sovereign Regional System?", Review of International Studies, 25(2): 201-223.

WILLIAMS, Michael (2003), "Words, İmages, Enemies: Securitization and International Politics", International Studies Quarterly, 47(4): 511-531.

ZOGLIN, Katie (2006), "The Future of War Crimes Prosecutions in the Former Yugoslavia: Accountability or Junk Justice?", Human Rights Quarterly, 27(1): 41-77. 